\title{
"A Review of Status, Problem and Prospects of Library Automation in Engineering Colleges of Jabalpur City"
}

\author{
Ashutosh Upadhyay ${ }^{1}$, Varsha Pandey ${ }^{2}$, B.P.Shrivastava ${ }^{3}$
}

\begin{abstract}
The study presents the review status of automation in Engineering College libraries and information centers of Jabalpur city in Madhya Pradesh. The uses of Information and communication Technology (ICT) facilitate easy \& immediate access to Information. During the process of Automation understanding and analyzing the various problems faced by the Management and the staff. The methodology adopted for the present study is survey using a structured questionnaire. It was observed that $52.63 \%$ of the Engineering College libraries were not automated for reason such as, Lack of computer facilities, Inadequate finance, Lack of trained Manpower; Management is not interested in library automation, collection from library is very less, tentativeness and lack of attitude towards automation and unsatisfactory library software problems are the major hindrances to speedy automation. Only $47.37 \%$ of Engineering College libraries are using automation to show that the libraries must be updated on the current scenario and the other libraries will follow these updates. This study also gives a status view of the software packages used by different engineering college libraries \& the opinion of the librarians \& library staff about the performance of software they use.
\end{abstract}

\section{Introduction}

Library is Heart of any institution .It is soul of any learning institution, which is pivot of teaching-learning process. College library plays an important role in providing overall library and information services to the patrons. We have just entered in new millennium and we have a lot of challenges before us for keeping in pace with modern development in information technology which have brought information explosion and information revolutiont. ${ }^{1}$

Computer is used in libraries to increase efficiency and effectiveness of their operation and services; they have also provided information management for taking effective decisions. Development and use of information and communication technology (ICT) enables the libraries not only to offer their clientele the appropriate information available within their Libraries but also gain access to catalogue of other libraries, both local and outstations. ${ }^{2}$

Automation of libraries has helped the libraries to keep pace with the latest Development. This has also facilitated accuracy, flexibility and reliability in the library and information centre. Automation of libraries reduces the repetitive work and save time and bring accuracy and speed. It also increases efficiency in technical processing of library materials and improve the efficiency of library administration and manager. ${ }^{3}$

\section{Review Of Related Literature}

Suku \& Pillai $(\mathbf{2 0 0 5})^{[4]}$ studied the present scenario of automation activities of university Libraries in Kerala. The survey findings mainly cover various aspects of library automation such as IT, infrastructure, in-house activities, information services \& their usage, manpower development, \& budget.Lohar and Kumber (2005) ${ }^{[5]}$ in their study on the present situation of college libraries in Shimoga District (Karnataka) have concluded that the situation do not meet the prescribed norms. Chakraborty and Maisal (2005) ${ }^{[6]}$ found library automation and networking do not depend only on the capacity of the computer or the networking server or even the software used since they are only tools. Much depends on the quality of manpower of the libraries and the perfection of the work they do. Sen (2005) ${ }^{[7]}$ studied on automation of a college library. According to her, entire library automation programmed requires judicious decision making at various stages. Such decision may be related to 'do it' or 'buy it' services, selection of hardware and software platform, application software, types of services to be rendered, etc. Bengal. The findings reveal that the networking of Government College libraries are in a conceptual stage and the idea comes to only one or two librarian. Singh (2005) ${ }^{[8]}$ discussed the state of agriculture libraries in India \& evaluate parameters. Such as need for Agriculture libraries association, Automation \& networking, agriculture documentation centre, professional development of library staff, professional's status etc. \& suggests measures for improvement of library services. Rajput \& Jain (2006) ${ }^{[9]}$ presents the status of automation in special libraries and information centers of Gwalior District in Madhya Pradesh. Aims at understanding and analyzing the various problems faced by the authorities and the staff during the process of automation.Shivram (2007) ${ }^{[10]}$ reported that:-For the successful implementation of an intrigrated library system all key factors must be in place: support from administration, staff competence, consideration of user requirements, and presence of the infrastructure hardware, software, and network), available data, excellent 
"A Review of Status, Problem and Prospects of Library Automation in Engineering Colleges of managerial skill from the coordinator of the project. Sinha \& Chakaraborty (2007) ${ }^{[11]}$ concluded that the status of computerization of library housekeeping operations and computer based library services of college libraries of southern Assam is in nascent stage. Only few colleges, Which are best colleges affiliated to Assam University, Silchar have started implementing project of automation and networking of their college libraries .The Govt. of Assam and UGC should come forward to provide substantial financial assistance to the colleges located in the remote area of South Assam, Which is popularly known as Barak Valley to start modernizing their college libraries and services to bring these colleges at par with the college libraries located in other parts of India. Barman \& Singh (2007) ${ }^{[12]}$ focuses on the manpower aspects of library automation in the college libraries of Assam. The status of automation has been discussed along with library survey, library software, and library services. Ramesh Babu, Vinayagamoorthy and Gopalkrishanan.S (2007) ${ }^{[13]}$ examined the extent and the level of ICT skills possessed by the_librarians of these institutions in their study. Hussein \& Ansari (2007) ${ }^{[14]}$ discussed the salient features of Cataloguing Module of three such packages, namely, Alice for Windows, Libsys \& Virtua \& their acceptability in a developing nation.Omirin \& Olayinka (2007) ${ }^{[15]}$ seeks to find out the advent of computer on libraries and information centre. Majority of the public libraries in Nigeria perform their operation manually and have no requisite technologies to easily access information resource and services most especially on the interest, on-line data bases and CD Rom databases and lack of skilled staff in Computerization. Computerization has a lot of Impact on library and information centers since it helps them to perform better then when their operation manually carried out.Haider (2007) ${ }^{[16]}$ explains that barriers to the effective implementation in the libraries of Pakistan are: systematic planning for automation, software and hardware collection, nonexistence of standards, financial limitations, uncertainty and most important lack of willing and competent human resources. In order to resolve the situation, the author stresses that special attention needs to be paid to: formulation of information policy; creation of popular awareness with regard to technology in library operation; training and development of staff; organization of users educational program for students and teachers; and emphasis on comprehensive planning by individual library to automate the library operations.Bansode \& periera (2008) ${ }^{[17]}$ discussed the status of automation in the colleges of goa is similar to that of college libraries throughout India. Libraries .librarians and college administration must initiate automation in order to provide effective \& efficient services to users. Library professionals must upgrade their skills in order to meet the growing expectations of users from libraries. Kushawah, Gautam \& Singh (2008) ${ }^{[18]}$ describes the observations and makes comparisons on the basis of discussion had with the library community using automation software in India. It also includes the information available in related literature. Features of library automation software, which are mostly in practice by libraries i.e. Libsys and SOUL, are compared with open source system KOHA. Gayakwad (2008) ${ }^{[19]}$ found that most of the university libraries the post of information scientist \& documentation officer are lying vacant. Only $28.57 \%$ libraries have started automation. Other $28.57 \%$ libraries have initiated automation as late as after 2005.Cent percent university libraries have provided Internet facilities in their libraries \& all of them use e-mail services frequently.Sangeeta $\&$ Sarika (2008) ${ }^{[20]}$ highlights the present status of academic libraries of Manipur particularly of college libraries of valley areas on varied aspects like-ICT based services, automation status and others including problem in ICT application. It also disclosed some suggestions to improve the service conditions of the college libraries. Harinarayan \& Raghvan (2008) ${ }^{[21]}$ examined the comparative retrieval effectiveness of the two packages, viz., CDSUISIS and Libsys Set of eight well-defined parameters were employed to compare the two packages. The result shows that neither of the two packages provides support for all the features that may be expected of ideal retrieval software. There appears to be some significant difference between CDSUISIS and Libsys in terms of their ability to provide desirable features. There is a difference of $9.34 \%$ in the levels of performance of the two packages.Rao (2009) ${ }^{[22]}$ studied on library automation facilitation in NIT libraries in India. He found that automation makes the library system, resources, and services more attractive and interactive, helping libraries to meet their users' expectations. In order to see the true picture of the provision of automation facilities among NIT libraries, this study has been conducted. There certainly was hopeful news provided by libraries have acquired ILS, and the majority of the libraries have automated their libraries is still in the developmental stages due to various technical, professional, and administrative reasons. Despite this, the NIT libraries will continue to managetheir library systems, functions, and services both manually and electronically with limited resource facilities, as they always have.Mulla (2009) ${ }^{[23]}$ studied intended to carry out a survey of engineering college libraries that have computerized their operations and services. Thus this paper will provide an implicit view of experiences undergone by the engineering college librarians in computerizing their library operations. It also observed that 13.73 percent of libraries are not automated reasons could be varied from library to library they were lack of computer facility, financial problems, lack of trained man power and library collection is very less. The present study is limited to the automated libraries of engineering college libraries in Karnataka. It gives a status view of the software packages used by different Opinion of the librarians about the performance of the software's different modules they have used. In India library automation began in the late 1970s in a few special libraries and has now reached most of the university libraries. It has yet to take off in college libraries in Karnataka owing to various problems. Many studies on library automation have been undertaken in the West, 
but few have been undertaken in India. This paper tries to identify the status of library automation in engineering college libraries of Karnataka state. Begum (2009) ${ }^{[24]}$ attempts to give a bird's eye view of the present scenario of library automation in the East West University \& discusses the satisfaction level of its user after improving automation system in this era of IT..Sahoo (2009) ${ }^{[25]}$ Studied on critical study of library services \& their modernization in university libraries of M.P.He found that most of the university libraries of M.P Received grant from INFLIBNET from establishment of infrastructure of computerization work. He found that a computer professional in University libraries is very poor. There is no information scientist in all the libraries in Jabalpur. "Ahmad (2009) ${ }^{[26]}$ Studied on Library Automation of Al-Barkaat Institute of Management Studies, Aligarh with help Alice for Window (AFW) Library Software. The study found that ABIMS Library is first fully automated library among all self financing Institutes available in Aligarh, which has provided, Online Services to its users through Inter Library LAN System in which users can access the library database from the Online Public Access Catalog (OPAC) and also helps to library staff to provide good reference service to staff and students. Mullah, Chandrasekhar (2010) ${ }^{[27]}$ study intended to carry out a survey of engineering college libraries that have computerized their operations and services. It provides an implicit view of the professional experiences of the engineering college librarians in computerizing their house keeping operations. Information was collected using a structured questionnaire mailed to 128 engineering college librarians, of which 102 (79.69\%) were received duly filled with all the relevant information requested in the questionnaire.Kannapanavar and Manjunatha(2010) ${ }^{[28]}$ found that $53.2 \%$ of users are using online public access catalogue (OPAC) to locate their reading materials, $48.8 \%$ of the users are consulting the librarian and library staff for locating the documents. $28.4 \%$ of users visiting the library once in a week followed by $7.4 \%$ visiting twice a week. $75 \%$ of all the users are spending less than $5 \mathrm{~h}$ per week in the library, $61.86 \%$ users are using reference services, and $48.5 \%$ of users are opined that they are getting their required reading materials within time. Modal \& Bandyopadhyay (2010) ${ }^{[29]}$ examines the situation of IT application and related manpower problems in government-aided general degree college libraries of Burdwan Sadar (North and South), West Bengal. Kumar \& Birder(2010) ${ }^{[30]}$ examine the use of information communication technology (ICT) in 31 college libraries in Karnataka, India by investigating the ICT infrastructure, current status of library automation, barriers to implementation of library automation and also librarians' attitudes towards the use of ICT.Kumar \& Kumar (2010) ${ }^{[31]}$ examines the situation of IT application and related manpower problems in government-aided general degree college libraries of Burdwan Sadar (North and South), West Bengal.Rajput \& Gautam (2010) ${ }^{[32]}$ Carried out to know the status of library automation and problems in their implementation in special libraries of Indore city, Madhya Pradesh. The study explained the various problems faced by authorities and the staff during the process of automation. The tool adopted to conduct the study is a well structured questionnaire. The staff hesitancy and lack of attitude towards automation and unsatisfactory library software problems are the major hindrances to speedy automation. It finally highlights the key suggestions for better implementation of library automation and to overcome the hurdles faced during pre and post automation. Jayaprakash \& Balasubramani (2011) ${ }^{[33]}$ Said that Automation of library operations and services is essential for efficient functioning of the library and saving the library users' time. Hence a study has been conducted to investigate the Automation in university libraries in Tamilnadu, India. It discusses automation, its need, and application in university libraries. The study explains the various problems faced by authorities and the staff during the process of automation. The tool adopted to conduct the study is a well structured questionnaire.Santosh (2011) ${ }^{[34]}$ discusses the importance of library automation, which helps librarians for excellent control over collection. New technologies library provides several new materials, media and mode of storing and communicating the information. Automation requires planning, designing, and implementation. Library automation reduces the drudgery of repeated manual efforts in library routine by use of library automation collection, Storage, administration, processing, preservation and communication etc. It increases productivity in terms of both works as well as in service.Rai \& Kumar (2011) ${ }^{[35]}$ discussed the progress of library management software and to trace out the characteristics and trends of software with special reference to packages that provide either web interface for some of their modules or total web-based solutions for all management modules. The paper also seeks to compare services and facilities and technologies incorporated in library automation packages.Farahi \& Gandhi (2011) ${ }^{[36]}$ carried out to investigate and compare the current state of information technology in medical libraries in Karnataka, India and Iran. Tools used for data collection included questionnaire, observational visits, and informal interviews with selected librarians. Although medical libraries in both countries have hardware, software, and communication facilities to some extent, they should strive to achieve excellent IT levels. A good number of libraries had library management software. However, only few medical libraries in both countries are fully automated. Iranian librarians ranked lack of institutional support, funds, trained and skilled professionals, and absence of planning and training courses, as the most important problems in IT application, while none of the options were rated as the most important problems militating against effective use of information technology by Indian medical librarians. The research compares the status of information technologies in India and Iran as developing countries and provides recommendations to promote library automation and effective application of 
"A Review of Status, Problem and Prospects of Library Automation in Engineering Colleges of information technology. Wodeyar \& Hadagali (2011) ${ }^{[37]}$ attempt has been in this study to know about the status of ICT infrastructure in the engineering college libraries in the Hyderabad-Karnataka region. Some measures have also been suggested for the improvement of existing ICT based resources and services.

\section{Findings}

- It was seen that only $10.53 \%$ (2) Engineering College libraries were fully automated, whereas $36.84 \%$ (7) were partially automated, and $52.63 \%$ (10) were not automated.

- In 19 engineering college libraries, it was found that $57.89 \%$ (11) of librarians had Master degree in library \& Information science. Where as $42.11 \%$ (8) had Post graduate Diploma in computer Application with M.Lib.Isc.

- It shows that out of 19 college libraries only $5.26 \%$ (01) has highest no. of reading materials and $15.78 \%$ (03) has lowest no. of reading materials.

- Majority of the Engineering college libraries have Server System, Client/computer work station CD/CDR Drives.77.78\%(7) have DVD/DVDR Drives ,Barcode Reader \& Laser Printers.66.67\%(6) have UPS.33.33\% have Barcode Printer \& scanner. Only $22.22 \%$ ( 2) have Dot matrix Printer

- $\quad$ The automated libraries were found to be using Software's which were available in Local Market and were hardly "Standard".

- Two popular modules viz; Circulation \& Cataloguing were in use in all the libraries which were automated.

- All $(100 \%)$ the libraries were taking recourse to Internet services for access to INDEST CONSORTIUM and few $66.67 \%$ ( 6) were using it for E-Mail \& Web browsing.

- All (100\%) of the libraries were using LAN mode of connection. Where MAN \& WAN were not use in anywhere.

- $\quad$ All (100\%) automated libraries were not having grant from any national network.

- It shows that out of 9 institutions only one has membership of INFLIBNET.

- It is seen that majority of the Engineering college libraries (66.67\%) offer On-line services, Internet search and On-line database search.

- It shows that all libraries faced Pre automation problems of lack of space as well as less interest of authority to upgrade IT skill of staff. On the other hand, in a few libraries, lack of interest of staff in learning IT applications is the problem.

- It is found that all libraries feel that computerization has increased productivity in terms of work output and information retrieval and helped in extending library services. The libraries have, however, divided opinions about the other prospects of computerization like economy in expenditure, enhanced the prestige of the library and increased user satisfaction.

\section{Suggestions}

- There is a need to computerize all the remaining (52.63\%) libraries in future for providing better and efficient services to readers.

- Vacant post of technical staff needs to be filled up and new posts should be created as per requirement.

- Computerized systems are dynamic rather than static. So it is important in planning for computerization, that hardware and software be selected which is sufficiently flexible to meet both the present and future needs. The hardware chosen must have the capacity to handle growth of the system for at least three to five years. The software chosen must also be flexible enough to accommodate additions and/ or changes to the system as need arises (Johnson, 1989).

- Librarian should conduct a survey of different automated libraries to exchange experiences before selecting software for their library.

- Choice of the library software must be carefully considered with emphasis on the ability to meet particular library needs.

- Librarian should evaluate each module before selection of library software, through receiving a demo of the software.

- Vendors should be scrutinized before selection and should be made to sign an agreement on the regular servicing and maintenance of the software purchased from them.

- There is the need for training and retraining of librarians in the use of information technology. Information literacy is also essential for all librarians who will be living and working in the $21^{\text {st }}$ century.

- $\quad$ Computer training should be provided and made mandatory for all the library staff .This mode of training programme will help the staff to practice and assimilate more .At the same time, it will also allow them to look after day -to-day work.

- $\quad$ IT based LIS education at B.L.I.SC \& M.L.I.SC. Level is must. 
"A Review of Status, Problem and Prospects of Library Automation in Engineering Colleges of

- $\quad$ Emphasis should be on buying standard library management s/w like LIBSYS, ALICE, SOUL etc. as they are found to be more satisfactory. Also this software allows data entry in standard form like CCF, MARC etc.

- User education program on emerging library technologies may be introduced to the library clientele especially freshmen.

- User education should be provided to make the user aware of the library collection as well as the services. User should also be given training so that he can handle the computerized system independently. important.

- Librarians should convince administrators at the higher level, in the importance of the use of computers, to develop a level of awareness at the administrators' level sufficient to encourage them to use the computer in libraries and to convince officials that automation will improve the effectiveness of information services and access to information which they need for decision making.

References

Sinha. M K, Chakraborthy. S K, Bhattacharjee.J.(2007) "Application of Information Communication Technology in college Libraries of Barak Valley (Southern Assam)".5th convention planner, Guhati, Ahmadabad: INFLIBNET centre Dec.7-8.

[2] Mulla KR, Chandrashekara M. (2010) "Use of Integrated library software: A survey of Engineering College Libraries in Karnataka”. International Journal of Information Science \& Management, vol.8, no.2, July-December.

[3] Sangeeta, K \& Sarika, L. (2008) Evaluation of ICT Based services in the academic libraries of Manipur: A Study. $6^{\text {th }}$ International CALIBER. Allahabad.

[4] Suku \& pillai. (2005) "Perspectives on automation of university libraries in Kerala status, problems \& prospects."

[5] Lohar, M.S. \& Kumber, M (2005) “College libraries in Shimoga district: A survey”. SRELS J. Inf. Manag. 42(3), 335-53.

[6] Chakaraborty, Abira \& Maisal, Anjali. (2005) Library automation and networking: A case study on Hoogly Mohsin College. In Automation and Networking of the College Libraries, edited by Biswajit Banerjee. Maulana Azad College, Kolkata, 224-25.

[7] Sen, P. (2005) Automation of a college library: Some issues. In Automation and Networking of the college libraries, edited by Biswajit Banerjee. Maulan Azad College, Kolkata, 125-26.

[8] Singh, N. (2005) "Revamping agriculture library \& information services in India: Retrospect \& prospect". Annals of library \& information studies 52,$1 ; 31-36$.

[9] Rajput \& Jain (2006). "Status of Automation in Special Libraries \& Information centers of Gwalior Survey.NCIMDiL.

[10] Shivram, B.S. (2007) "Library automation: an overview".

[11] Sinha.M, Chakarborthy.S, Bhattacharjee.J, (2007) "Application of Information communication Technology in college Libraries of Barak Valley (Southern Assam)", Ahmedabad: INFLIBNET centre, 7-8.

[12] Barman, RK \& Singh, SK. (2007) HRD Aspects of library automation in college libraries of Guwahati: A Study. $5^{\text {th }}$ convention planner-2007, Guwahati, Dec.7-8,.INFLIBNET centre.Ahamadawad.

[13] Babu.R, Vinaygamoorthy.P \& Gopalkrishanan.S (2007).ICT Skills among librarian in Engineering educational institution in Tamilnadu.Desidoc bulletin of I.T, Vol.27, No.6, pp55-64.

[14] Hussain,S \& Ansari, MA. ( 2007.) Library Automation software packages in India: A Study of the Cataloguing Modules of Alice for Windows,Libsys \& Virtua .Annals of Library \& Information Studies.Vol.54,pp.146-151.

[15] Omirin, MS \& Olayinka, EA. (2007).Computer as a tool in library \& Information centers .Asian Journal of Information Technology. 6(4):486-488, 2007.

[16] Haider, Jala-ud-Din Syed (2007). Library management scenario \& management problems in Pakistani libraries. Library Administration \& Management, vol. 21, no.4, fall 2007. pp.173-176

[17] Bansode, S.Y. \& Pereira's. (2008) A survey of library automation in college libraries in goa state: library philosophy \& practice.

[18] Kushwaha, s, Gautam, JN \& Singh, R (2008).Library Automation \& open source solution Major shifts \& practices: A Comparative case study of Library Automation System in India. CALIBER.

[19] Gayakwad, Kalpana. (2008)Library automation in university libraries in Uttaranchal state.

[20] Keisham, Sangeeta \& Sarika, L (2008).Evaluation of ICT Based services in the Academic libraries of Manipur:-A study.6 ${ }^{\text {th }}$ International CALIBER-2008, University of Allahabad, Feb 28-29 \& March 1.

[21] Harinarayan, N.S. \&Raghavan, K.S. (2008).Retrieval capabilities of CDSUSIS and Libsys: A comparison. Annals of library and information studies, 55(2), 91-100.

[22] Rao, Y \& Choudhary, B.K. (2009).Library automation facilitation: A Case study of NIT Libraries in India

[23] Mulla, KR (2009).A Journal of Library and Information Science: 2009, Volume : 3, Issue : 3

[24] Begum, Dilara. (2009)East west university library: A Model of automated Information services.ICAL2009-Poster papers.

[25] Sahoo, Mukesh Kumar. (2009)Critical study of library services \& their modernization in University libraries of M.P

[26] Ahmed, Parvez. (2009) Library Automation of Al-Barkaat Institute of Management Studies, Aligarh with help Alice for Window (AFW) Library Software. Indian Journal of Library and Information Science; Vol.3 No.2

[27] Mullah, K. R. Chandrashekara, M.( 2010)Use of Integrated library software survey of Engineering college libraries in Karnataka. International Journal of Information Science \& management, Vol.8, No.2

[28] Kannapanava BU \& Manjunatha KV (2010). Library use pattern by the faculty members of the engineering colleges in Karnataka: A study .International Journal of Library and Information Science Vol. 2(8), pp. 155-163.

[29] Mondal AK \& Bandyopadhyay AK (2010).Application of ICT \& Related manpower problems in the college libraries of Burdwan. Desidoc Journal of Library \& Information Technology, Vol.30, No.4, pp44-52.

[30] B.T. Sampath Kumar, B.S. Biradar, (2010) "Use of ICT in college libraries in Karnataka, India: a survey", Program: electronic library and information systems, Vol. 44 Iss: 3 , pp. $271-282$.

[31] Kumar Arup r \& Kumar Amit.(2010).Application of ICT and Related Manpower Problems in the College Libraries of Burdwan,DESIDOC Journal of Library \& Information Technology, Vol. 30, No. 4,pp. 44-52

[32] Rajput, PS \& Gautam (2010), JN. Automation and problems in their implementation: An investigation of special libraries in Indore, India.International journal of library and information science, Vol.2 (7), pp.143-147.

[33] Jayaprakash, M \& Balasubramani, R. (2011) Status of Automation in University Libraries of Tamilnadu: A Survey European Journal of Scientific Research, Vol.53 No.1, pp.17-24. 
[34] Santosh, Gavali Vandana. (2011).Impact of Library automation in the development Era: A case Study Vol - I, ISSUE - V [June]: Library Science.

[35] Rai, Namrata \& Kumar, Shailendra (2011) "Comparative features of integrated library management software systems available in Delhi", Electronic Library, the, Vol. 29 Iss: 1, pp.121 - 146.

[36] .Farahi, Mina Tavassoli and Gandhi, R. T. D.( 2011) Ramesh. Adoption of information technologies in medical libraries in Karnataka, India and Iran: A comparative stud International Journal of Library and Information Science Vol. 3(2), pp.38-45, ISSN 2141 - 2537 C2011 Academic Journals.

[37] Wodeyar, R \& Others. (2011)Information and communication Technology (ICT) infrastructure: A Study of engineering college libraries in Hyderabad - Karnataka region. The Indian journal of technical education, Vol.34.No.1.

\section{ABOUT THE AUTHORS}

Ashutosh Upadhyay was born in Jabalpur on 11th Aug.1980. He has done M.Phil in Library \& Information Science in 2009 He is presently doing PhD. in Library \& Information Science from CMJ University, Shillong (Meghalaya), India

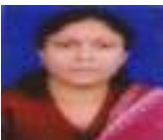

Varsha Pandey was born in Jabalpuron 03-july-1968. Hehas done M.Phil in Library \& Information Science in $2009 \mathrm{He}$ is presently doing PhD. in Library \& Information Science from CMJ University, Shillong (Meghalaya), India. 